\title{
Environmental costs as an indicator of sustainable development
}

\author{
Svetlana Egorova $^{\mathbf{1}}$, Irina Bogdanovich ${ }^{\mathbf{1}}$, Natalia Kistaeva ${ }^{\mathbf{1}}$ and Anastasia Kulachinskaya ${ }^{\mathbf{2}}$ \\ ${ }^{1}$ Pskov State University, Pskov, Russian Federation \\ ${ }^{2}$ Peter the Great St. Petersburg Polytechnic University, St. Petersburg, Russian Federation
}

\begin{abstract}
One of the priorities of the modern economy is the optimal use of natural resources in economic activity. This is because the organization and management of production impacts the environment, which in turn affects both the well-being of society and the indicators of economic development. Which is why methodology and practice of public non-financial reporting reflecting indicators related to the conservation and assessment of natural resources, pollution control, waste management and recycling, and creating emission standards are actively developing. Environmental costs are becoming an important tool for making informed management decisions aimed at harmonizing the economy and the environment. At present, despite a large number of methodical developments, there is no solid theoretical basis for the formation of environmental indicators that adequately characterize the interaction of the economy and the environment and economic decision-making at all levels. The article clarifies the content, classification, performance evaluation system, environmental cost assessment methods for their application in management activities for deeper analysis, modelling and predicting economic phenomena and processes within the framework of the concept of sustainable development. The authors show approaches to the valuation of anthropogenic damage to nature, determined by the disproportionateness of natural and value indicators; the lack of prices of non-market goods, great uncertainty about the true value; the duration of the effects of man-made impacts and the long-term investment in environmental protection. Modern approaches to modelling and interpretation of results are generalized, as well as the possibilities of developing new (or improving existing) models for optimizing environmental costs. The direction of analysis of environmental indicators in the existing management system has been defined, in particular, through the study of non-financial reporting, which acts as a basis for calculating resource utilization, environmental quality and sustainability.
\end{abstract}

\section{Introduction}

The reporting requirements for organizations are now beginning to change. Investors take into account not only financial but also non-financial factors in making strategic decisions, which allows them to assess the strategic investment attractiveness of the company, as well as to predict the duration of the company's activities. Thus, only financial indicators, formed in standard reporting forms, are not enough to assess the prospects for the company's development.

Economic decision-making requires accounting to fully and reliably reflect the full and true range of relationships between strategic, managerial, operational, financial and non-financial components, showing how the organization implementing its successful business model, uses a variety of capitals (financial, production, intellectual, human, natural and social), interacts with the external environment and assesses its ability to continue to operate on for the sufficient time.

Efforts have already been made at the international level to address the problem. In 1997, for example, the Global Reporting Initiative (GRI) was established by the Environmentally Responsible Business Coalition, which developed the "extended" report needed to provide a sustainable development summary to all the interested parties.

The purpose of such reporting is to improve business on the way to a sustainable global economy, in which long-term profitability is combined with social responsibility and environmental care.

GRI management is constantly improving approaches to reporting information. In early 2014, an updated G4 guide was published, the fourth version of the requirements for the presentation of non-financial and financial information [1].

The development of sustainable development reporting involves disclosing not only financial indicators, but also information related to conservation and assessment of natural resources, pollution control management and recycling of waste, as well as the creation of emission standards. Environmental costs are becoming an important tool for making informed management decisions aimed at harmonizing the economy and the environment.

At present, despite a large number of methodical developments, there is no solid theoretical basis for the formation of environmental indicators that adequately characterize the interaction of the economy and the environment, and are required for economic decisionmaking at all levels.

\section{Literature review and research methods}

The inclusion of the concept of sustainable development in the strategies of countries, regions and

* Corresponding author: es1403@bk.ru 
enterprises has predetermined the revitalization of research in the sphere of mutual impact of economic development processes and changes in the state of the natural environment. The main challenge of such studies is to achieve the optimal effect while maintaining a dynamic equilibrium of ecosystems [2]. From an economic point of view, the best solution to environmental problems is to achieve this level of environmental impact in which environmental costs, including both environmental damage and recovery (prevention) costs, are minimal. Particular attention is paid to identifying patterns linking environmental and economic characteristics, which is related to the search for a balance between interests in development in a particular area of certain types of economic activities and the need to ensure the reproduction of self-regulating natural systems [3].

Environmental constraints affect the productivity of an individual enterprise, an industry [4], and economic development of a region, a country and humanity as a whole. Economic actors, on the one hand, are looking for ways to reduce costs and, on the other hand, are interested in preventing critical environmental impacts, i.e. reducing environmental risks. At the same time, an important problem in assessing the effectiveness of environmental measures is that the indicators in the "goals-environmental cost-result" chain are of different nature [5]. If the goals and expected effect of environmental measures are determined by environmental indicators of the state of the environment (reducing the concentration of harmful substances, preserving species diversity and population size, etc.), expressed in natural measurement units, then economic goals, environmental costs and their expected economic result are evaluated.

Therefore, the goal of optimizing environmental costs by incorporating them into economic analysis environment at different levels of government (enterprise, region, national economy in whole) has spawned many approaches to addressing it.

In the scientific and methodical literature, the costs of environmental activities are linked to additional costs and losses to the economy, which are a consequence of the poor state of the natural environment and represent an economic damage from environmental violations [6].

However, the methods used to determine the damage do not provide an objective assessment, which is necessary in the development of pre-project and project documentation, conducting environmental audits of enterprises, assessing the effectiveness of investment projects, or insuring environmental risks.

Among the significant problems we can highlight the following:

Firstly, the lack of a unified methodology for all the types of natural environments, technologies and industries; the mismatch of damage calculated using different methods; the lack of accounting for a number of physical and chemical properties of harmful substances, and the fact that accumulated damage to natural systems is not taken into account [7]. Thus, research in this direction continues to be among the pressing issues of the environmental economy.
Secondly, the approach considered, based on the category of economic damage from environmental violations, assesses not the negative processes in ecosystems, but their impact on economic activity, which can be evaluated. At the same time, environmental aspects of environmental harm are restricted by established limits, and the possibility of a catastrophic outcome of events, humanistic and moral issues remains outside the scope of economic assessment. This means that environmental costs should be planned not only in terms of the cost-effectiveness of environmental measures (to phrase it differently, the costs are less than the damage prevented plus compliance with pollution standards is achieved) but also in terms of the opportunities available to society in the current state of the economy and the level of technological and technical development.

Thirdly, environmental costs are borne by economic agents of different scales: countries, regions, enterprises, individuals. This means that there is a need to match costs and benefits at different levels of economic decision-making.

Fourthly, assessment and evaluation of damage is due to the economic assessment of natural benefits, the complexity and dubitability of which, despite the presence of a large number of practical methods, is due to the disproportionateness of natural and value indicators, lack of prices of non-market goods, uncertainty about their true value, duration of damage and long-term environmental investment and the associated uncertainty in choosing a discount rate in which the economic and moral aspects are intertwined [8].

One of the most acute and complex problems the environmental economy faces is the economic evaluation of environmental assets. The main reasons for the need to obtain a monetary value of environmental resources include: cost-benefit analysis; environmental accounting; assessment of damage to natural resources and proper pricing; development of environmental accounts and their integration with national accounts, creation of environmentally adjusted macroeconomic indicators, including green GDP; search for universal criteria for sustainable development $[9,10,11,12,13,14]$.

Table 1. The approaches

\begin{tabular}{|c|c|c|c|}
\hline $\begin{array}{c}\text { Conce } \\
\text { pt }\end{array}$ & Essence & Examples & Criticism \\
\hline Costs & $\begin{array}{l}\text { The cost } \\
\text { of the } \\
\text { resource } \\
\text { is } \\
\text { determin } \\
\text { ed by the } \\
\text { cost of } \\
\text { labor to } \\
\text { develop } \\
\text { them and } \\
\text { get them } \\
\text { involved } \\
\text { in } \\
\text { economic } \\
\text { turnover }\end{array}$ & $\begin{array}{l}\text { Economic assessment } \\
\text { of land by S.G. } \\
\text { Strumilin: } \\
\qquad E=\bar{K} \cdot\left(\frac{Y}{\bar{C}}: \frac{\bar{Y}}{\bar{C}}\right), \\
\text { where } \\
E \text { is economic estimate } \\
\text { of } 1 \text { hectare of land; } \\
\bar{K} \text { is average cost of } \\
\text { developing } 1 \text { hectare of } \\
\text { land; } \\
\frac{Y}{C} \text { and } \frac{Y}{\bar{C}} \text { are the ratio of } \\
\text { the product's yield to } \\
\text { the current production } \\
\text { costs at the estimated } \\
\text { site and the national } \\
\text { average [15]. }\end{array}$ & $\begin{array}{l}- \text { A } \\
\text { resource of } \\
\text { better quality } \\
\text { receives lower } \\
\text { value, while } \\
\text { more difficult } \\
\text { to use get } \\
\text { higher rated; } \\
\text { - lack of } \\
\text { consideration } \\
\text { of quality } \\
\text { features of } \\
\text { natural } \\
\text { resources. }\end{array}$ \\
\hline
\end{tabular}




\begin{tabular}{|c|c|c|c|}
\hline $\begin{array}{c}\text { Conce } \\
\text { pt }\end{array}$ & Essence & Examples & Criticism \\
\hline Rent & $\begin{array}{l}\text { The } \\
\text { evaluatio } \\
\mathrm{n} \text { of the } \\
\text { resource } \\
\text { is } \\
\text { determin } \\
\text { ed by the } \\
\text { size of } \\
\text { the } \\
\text { differenti } \\
\text { al rent it } \\
\text { is } \\
\text { making* }\end{array}$ & $\begin{array}{l}R=\sum_{\mathrm{i}=0}^{K} \frac{R_{i}}{(1+r)^{1}} \text {; } \\
R_{\mathrm{T}}=\sum_{j=1}^{m}(Z-S) \cdot n_{j} \\
\text {, where } \\
R \text { is an economic } \\
\text { assessment of the } \\
\text { resource; } \\
K \text { is a number of years } \\
\text { the resource has been } \\
\text { used; } \\
r \text { is discounting rate; } \\
R_{\mathrm{T}} \text { is the size of the } \\
\text { annual rent; } \\
Z \text { and } S \text { are closing } \\
\text { costs and costs per unit } \\
\text { of production; } \\
n_{j} \text { is the amount of } \\
\text { product of } j \text {-th type } \\
\text { [15].Ошибка! } \\
\text { Источник ссылки не } \\
\text { найден. }\end{array}$ & $\begin{array}{l}- \text { It is } \\
\text { difficult to } \\
\text { differentiate } \\
\text { rent from } \\
\text { additional } \\
\text { income due to } \\
\text { better } \\
\text { production } \\
\text { organization, or } \\
\text { application of } \\
\text { better } \\
\text { technologies; } \\
- \\
\text { ent of facilities } \\
\text { that are } \\
\text { managed } \\
\text { poorly is zero. }\end{array}$ \\
\hline
\end{tabular}

The approaches presented above (Table 1) do not take into account, at least, those natural benefits that are not used to achieve production goals, but are viewed as elements of the well-being of society.

In international practice, environmental economists distinguish between types of economic values depending on the use and non-use of the value of environmental goods (see Figure 1). Use values (UV) are divided into direct (for example, the cost of wood in the forest) and indirect (for example, the cost of carbon sequestration by forests). Non-use value (NUV-the cost of non-use) is the value that people attach to the environmental good, regardless of whether they use it themselves or not [16]. The total economic value of natural goods (TUV) consists of individual use values and non-use values (see Figure 1) [17].

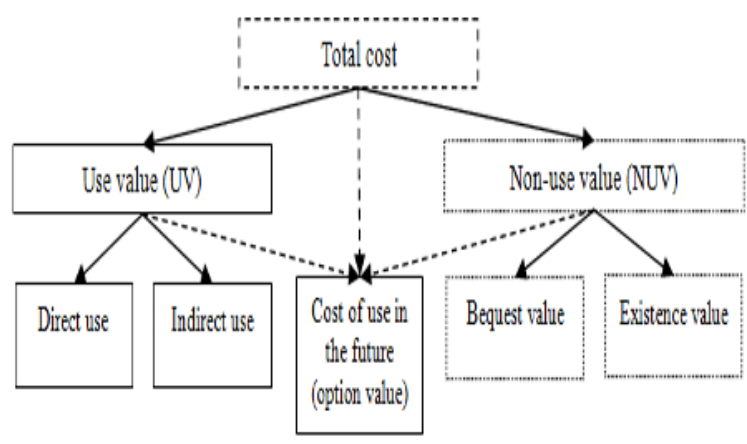

Fig. 1. Total economic value of environmental benefits (Source: [17]).

The choice of method and valuation depends on the forms of cost (UV or NUV) [18]. Market prices provide an equilibrium assessment at the current level of supply and demand, can be used to calculate the cost of damages caused by environmental violations, for example, if products cannot be produced or a loss of property occurs, but they cover only direct consumer value. Therefore, they are not a measure of the total economic value for natural goods.
The basic methods of value assessments of natural goods are presented in table 2 .

Critics of monetary assessment of natural benefits point to its laboriousness and resource-intensiveness; the need to update previous assessments and, as a result, being forced to use outdated or inappropriate assessments; ethical problems, as well as many other shortcomings [21]. Meanwhile, they indicate that the economic value of environmental goods depends on the level of socio-economic development achieved by society: a natural resource that has a consumer value today, tomorrow can be awarded the highest value as part of the general heritage of society [22].

Over the past two decades, there have been major changes in the empirical methods used by economists to explore the problem of sustainable development. The development of the research design was facilitated by increased computing power and the availability of large datasets [2].

W. Nordhaus, winner of the 2018 Nobel Prize in Economics "for integrating climate change into long-run macroeconomic analysis ", pioneered in modeling interconnections between economic and ecological indicators [23]. An important innovation of the Nordhaus DICE and RICE models is the idea of combining into a single system equations containing economic variables and physical variables (characteristics of the carbon cycle, radiation exposure of greenhouse gases) to study the relationship between climate and economic damage.

\section{Results and Discussion}

Environmental costs accompany "a system of negative impacts of the economy on nature and the reverse negative impacts of the disturbed natural environment on the economy" [6] and are the sum of interdependent economic costs: the cost of compensating for environmental violations and environmental costs to prevent these violations (see Figure 2).

The amount of such costs is called economic damage caused to the national economy by environmental violations $[6,24,25]$. It is not permanent and depends on many reasons, including the physical, chemical and biological parameters of the natural environment and negative factors of economic activity. The relationship between the two types of costs is supposed to be divergent: as environmental costs increase, the cost of damages should be reduced, and vice versa.

Such an approach to environmental costs allows us to give an economic justification to the goals of environmental activities by assessing the economic damage from environmental violations and correlating the costs and benefits of environmental measures, as well as to show the validity of the assessment of natural resources by determining the damage from the loss of a unit of this resource as a result of environmental violations, and propose various methods for evaluating damage (for example, using the intersectoral balance based on expert estimates) $[6,24,25,26,27]$. 
Table 2. Methods for evaluating natural goods

\begin{tabular}{|c|c|c|c|}
\hline \multicolumn{2}{|c|}{ Methods } & \multirow{2}{*}{$\begin{array}{l}\text { Essence } \\
\text { Total cost of damage based on information on } \\
\text { the costs of related market goods: the value of } \\
\text { lost property, the cost of production losses }\end{array}$} & Problems \\
\hline \multirow[t]{3}{*}{$\begin{array}{l}\text { Revealed } \\
\text { Preference } \\
\text { Methods }\end{array}$} & $\begin{array}{l}\text { Market price } \\
\text { proxies }\end{array}$ & & $\begin{array}{l}\text { need to collect information on } \\
\text { market prices, accounting for } \\
\text { seasonal price fluctuations and } \\
\text { inflation; } \\
\text { - market failures distort prices; }\end{array}$ \\
\hline & $\begin{array}{l}\text { Transport costs } \\
\text { method }\end{array}$ & $\begin{array}{l}\text { Modeling the function of the demand for rest } \\
\text { and calculating the surplus of the consumer. } \\
\text { The cost of paying for quality is determined } \\
\text { by differences in the cost of visiting tourism } \\
\text { destinations with varying quality. }\end{array}$ & \multirow[t]{2}{*}{$\begin{array}{l}\text { need to link market data to } \\
\text { environmental characteristics; }\end{array}$} \\
\hline & $\begin{array}{l}\text { Hedonic property } \\
\text { pricing }\end{array}$ & $\begin{array}{l}\text { Value of a product, such as real estate, is } \\
\text { explained as a set of characteristics of which } \\
\text { one or more may be environmental. We are } \\
\text { using regression analysis to assess the } \\
\text { influence of various factors on the value of the } \\
\text { object. }\end{array}$ & \\
\hline \multirow[t]{2}{*}{$\begin{array}{l}\text { Stated } \\
\text { Preference } \\
\text { Methods }\end{array}$} & Appraisal method & $\begin{array}{l}\text { Individuals evaluate environmental quality } \\
\text { values through surveys asking them to } \\
\text { indicate their preferences. Both UV and NUV } \\
\text { are taken into account [19]. }\end{array}$ & \multirow{2}{*}{ 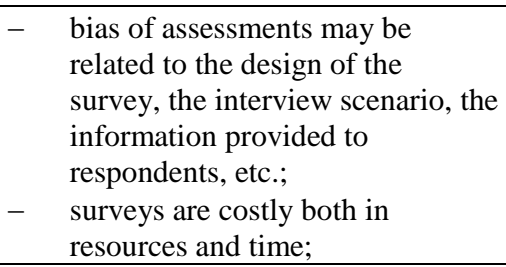 } \\
\hline & $\begin{array}{l}\text { Choice modeling } \\
\text { (market } \\
\text { simulation) }\end{array}$ & $\begin{array}{l}\text { Multicriterial method, where one of the } \\
\text { attributes is the costs [19]. }\end{array}$ & \\
\hline \multicolumn{2}{|c|}{ Production Function Approach } & $\begin{array}{l}\text { Assessing the function of physical harm for } \\
\text { projects impacting environment }\end{array}$ & $\begin{array}{l}\text { difficulties with complex } \\
\text { environmental and economic } \\
\text { interdependencies, and the } \\
\text { presence of feedback [20]; }\end{array}$ \\
\hline \multicolumn{2}{|c|}{ Replacement Cost Method } & $\begin{array}{l}\text { Use of information about the relationship } \\
\text { between a product that does not have a market } \\
\text { and a product that has a market. Direct } \\
\text { replacement of a product that does not have a } \\
\text { market with a product that has a market. The } \\
\text { indirect substitution method combines } \\
\text { substitution and production function. }\end{array}$ & 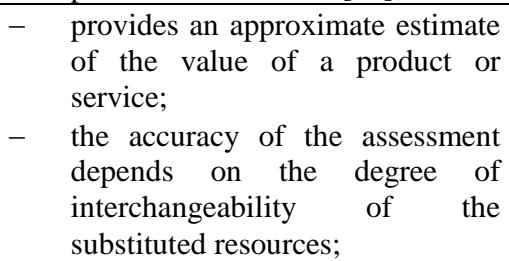 \\
\hline \multicolumn{2}{|c|}{$\begin{array}{l}\text { Preventive Cost Method (to reduce } \\
\text { negative impact) }\end{array}$} & $\begin{array}{l}\text { Measures the cost of preventing damage, can } \\
\text { be used to measure the impact of biodiversity } \\
\text { loss on market and non-market goods and } \\
\text { services, with the exception of unused values. }\end{array}$ & $\begin{array}{l}\text { - data on actual costs incurred to } \\
\text { alleviate environmental concerns } \\
\text { is needed; }\end{array}$ \\
\hline \multicolumn{2}{|c|}{ Dose-Reaction Method } & $\begin{array}{l}\text { Based on the connection between pollution } \\
\text { and public health indicators, requires data } \\
\text { reflecting the relations between human, } \\
\text { animal or plant response to pollution }\end{array}$ & $\begin{array}{l}\text { - uncertainty of the function of the } \\
\text { reaction is related to the } \\
\text { complexity of the relationship } \\
\text { between pollution and health; } \\
\text { the accuracy of the method is not } \\
\text { known and can lead to errors in } \\
\text { assessing the benefits of } \\
\text { improving the quality of the } \\
\text { environment; }\end{array}$ \\
\hline \multicolumn{2}{|c|}{ Alternative Cost Method } & $\begin{array}{l}\text { Instead of assessing the benefits of improving } \\
\text { the quality of the environment, we consider } \\
\text { the benefits of activities that lead to } \\
\text { environmental damage, which are accepted as } \\
\text { lower limits on the value of environmental } \\
\text { objects, showing how valuable it should be to } \\
\text { preserve them in their current form }\end{array}$ & \\
\hline
\end{tabular}

pollution. The resulting economically optimal level should be compared with the maximum allowable level according to the established standards. If the economic

Since the averted and caused damage are the cost of the same economic agent that seeks to minimize their sum, it becomes possible to minimize the amount of environmental costs and economic damage from pollution and to define an economic optimum of level does not exceed the standard one, then the results of the optimization problem are accepted, otherwise the economically optimal solution is discarded [25].

Based on an understanding of the environmental costs presented in the Figure 2, the formation of 


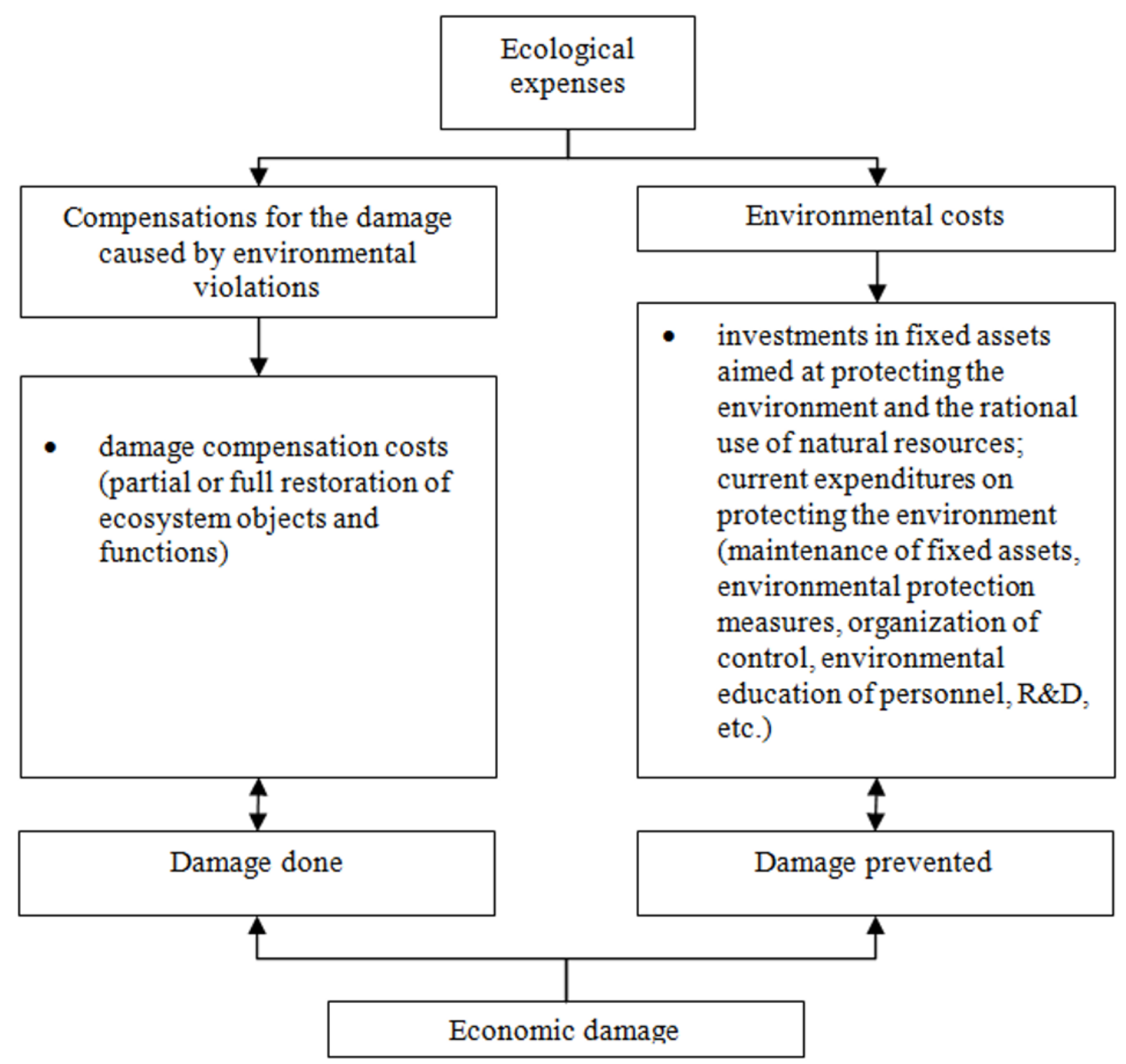

Fig. 2. Environmental costs and economic damage from environmental violations.

information begins with getting adequate assessments of the damage caused and the averted damage.

As discussed above, the different nature of the indicators characterizing targets, means and expected results of environmental protection measures is an important issue in assessing environmental costs. One of the approaches to solving this problem is the development of Integrated Assessment Models (IAM). The aim of developing such models is to provide information for sound management decisions in the areas of economic and environmental policy. Environmental characteristics in these models tend to be selected in the context of climate change, so they describe the processes that produce greenhouse gases. At the same time, all climate models of integrated assessment include the characteristics of the economic processes.
The features of integrated assessment models are their interdisciplinary approach, different levels of detail and complexity of the relationships taken into account, global geographical coverage, and long-term time horizon.

We can use two types of IAM:

1. Process-based Integrated Assessment Models that focus on quantifying development scenarios and provide industry-based information based on complex processes modeled.

2. Cost-benefit Integrated Assessment Models that are models of policy optimization, they have a goal function or a welfare function, which gets maximized and can be used to evaluate alternative trajectories or policies [28].

Integrated modeling of the relationships between natural changes and macroeconomic processes is aimed at assessing the damage from emissions of a greenhouse gas unit - the "social cost of carbon emissions" (SCC, 
social cost of carbon) [29], analysis of complex scenarios for fighting climate change; at the assessment of costs and benefits, divided in time and falling on different generations, under conditions when neither the economic damage from climate change, nor the costs of reducing greenhouse gas emissions can be accurately known; at the development of economic and environmental policies at the global level, etc. [28].

We should also note that there are important flaws in integrated modeling, which make it virtually useless as a tool for policy analysis because IAM-based analysis of climate policies creates a perception of knowledge and accuracy that is illusory, and can make policymakers think that the predictions generated by the models have scientific legitimacy of sorts [30,31].

Among these drawbacks are the following:

1) Unreasonable choice of functional forms and values of model parameters, such as the discount rate when determining SCC, the choice of which leads to strikingly different conclusions about the optimal reduction in emissions. The equations, which are part of most IAM, are nothing more than reflections of the modeler's own "expert" opinion, and thus the model can be used to obtain almost any desired result to legitimize subjective views on climate policy.

2) Attempt to take into account in IAM the relationship between increasing $\mathrm{CO} 2$ concentrations and rising global temperatures in the absence of accurate knowledge of physical mechanisms of such interconnection, uncertainty regarding climate sensitivity.

3) Lack of understanding of the actual form of function of damage, which is one of the most important parts of IAM and describes the relationship between temperature growth and GDP (or GDP growth). The scientific literature contains very little information about the damage to the economy that can ensue from rising temperatures.

4) The probability of a climate catastrophe developing due to a sharp rise in global temperature, which will cause significant damage to the economy, is unknown, but it is these events that should be the focus of environmental policy [31].

The final stage in the formation of information on environmental costs is their reflection in accounting. Within the framework of the concept of sustainable development, environmental responsibility is an important component of business sustainability. Using non-financial reporting indicators will allow stakeholders to analyze spending on environmental protection; estimate emissions in the atmosphere, use of water resources, waste generation, impact of land and vegetation conservation, as well as the conservation of biodiversity, energy and energy efficiency.

\section{Conclusion}

As part of the concept of sustainable development, environmental costs have become an important tool for assessing economic development and the well-being of society. Lately, a lot of attention is paid to clarification of their content, classification, methods and methodology of their assessment, modeling the relationship between economic and environmental indicators.

Despite this, we should note that there is a problem of lack of data, as well as overestimation and underestimation of environmental costs due to the divergence of estimates obtained using different methods.

Given that the level of confidence in reporting environmental costs in non-financial reporting determines the quality of management decisions made, the issues of presenting systematic data on the value of environmental costs in accounting need further development.

Ways of organizing environmental accounting require comprehensive analysis as well; further development of the methodology for integrating environmental indicators into the accounting system is needed, as well as the use of such accounting data for adoption of better sustainable development solutions. This is because it is the environmental accounting that provides valuable tools for analyzing the economic impact of environmental problems.

\section{References}

1. The GRI Standards: the global standards for sustainability reporting, Global Reporting Initiative, Amsterdam, Netherlands

2. S. Polasky, C. L. Kling, S.A. Levin, S.R. Carpenter, G.C. Daily, P. R. Ehrlich, G.M. Heal, J. Lubchenco, Role of economics in analyzing the environment and sustainable development, PNAS (Proceedings of the National Academy of Sciences of the United States of America) 116(12): 5233-5238 (2019)

3. J.C.J.M. Van Den Bergh, M.W. Hofkes, A survey of economic modelling of sustainable development, Theory and Implementation of Economic Models for Sustainable Development. Economy \& Environment, vol 15. Dordrecht: Springer (1998)

4. S. Albrizio, K. Tomasz, V. Zipperer, Environmental policies and productivity growth: Evidence across industries and firms, Journal of Environmental Economics and Management 81: 209-226 (2017)

5. S. Hansson, Philosophical problems in cost-benefit analysis, Economics and Philosophy, Cambridge Univ Press, 23(2): 163-183 (2007)

6. E. V. Ryumina, Damage indicator as an economic tool for preserving the environment, Institute of Market Problems of the Russian Academy of Sciences. Proceedings VII of the All-Russian Conference "The Theory and Practice of Environmental Insurance: Sustainable Development": 110-124 (2007)

7. E. Loginov, A. Tulupov, Assessment of harm from environmental law violations, Standards and quality 2 28-32 (2015)

8. R. Perman, Yue Ma, J. McGilvray, M. Common, Natural Resource and Environmental Economics, 3-rd ed., Pearson Education Limited (2003) 
9. K. Obst, L. Hein, B. Edens, National accounting and the valuation of ecosystem assets and their services, Environmental and Resource Economics 64(1): 1-23 (2016)

10. K. Arrow, P. Dasgupta, L. H. Goulder, K. J. Mumford, K. Oleson, Sustainability and the measurement of wealth, Environment and Development Economics, Cambridge University Press 17(03): 317-353 (2012)

11.C. Perrings, Environment and development economics 20 years on, Environment and Development Economics 19(3): 333-366 (2014)

12.B. Hannon, Ecological pricing and economic efficiency, Ecological Economics 36: 19-30 (2001)

13. H. S. Matthews, L. B. Lave, Applications of Environmental Valuation for Determining Externality Costs, Environmental Science \& Technology 34: 13901395 (2000)

14.E. Barbier, Wealth accounting, ecological capital and ecosystem services, Environment and Development Economics, 18(2): 133-161 (2013)

15. O. S. Shimova, N. K. Sokolovsky, Basics of ecology and the economy of environmental management, Mn: BGEU (2002)

16. S. Ahlroth, M. Nilsson, G. Finnveden, O. Hjelm, E. Hochschorner, Weighting and valuation in selected environmental systems analysis tools - Suggestions for further developments, Journal of Cleaner Production 19: 145-156 (2011)

17. The economic significance of natural resourses: key points for reformers in Eastern Europe, Caucasus and Central Asia, OECD (2011)

18. S. Abdullah, A. Markandya and P. A. L. D. NUNES, Introduction to Economic Valuation Methods, Research Tools in Natural Resource and Environmental Economics, 5: 143-187, US: World Scientific (2011)

19. P. Boxall, W. Adamowicz, J. Swait, M. Williams, J. Louviere, A comparison of stated preference methods for environmental valuation, Ecological Economics 18: 243-253 (1996)

20. Y. Chee, An ecological perspective on the valuation of ecosystem services, Biological Conservation, 120: 549-565 (2004)

21.F. Ackerman, L. Heinzerlin, Pricing the priceless: Cost-benefit analysis of environmental protection, University of Pennsylvania Law Review 150: 1553-1584 (2002)

22. D. Azqueta, D. Sotelsek, Valuing nature: From environmental impacts to natural capital, Ecological Economics 63: 22 - 30 (2007)

23. Scientifc Background on the Sveriges Riksbank Prize in Economic Sciences in Memory of Alfred Nobel 2018 "Economic growth, technological change, and climate change" (2018)

24. Temporary model methodology for determining the cost-effectiveness of environmental measures and assessing the economic damage caused to the national economy by pollution (approved by the USSR State Plan Resolution, State Building of the USSR, Presidiums of the USSR AN from 21.10.1983 N 254/284/134), ConsultantPlus (2019)
25. E. V. Ryumina, Analysis of environmental and economic interactions, In-t problems of the RAS market, Moscow : Science (2000)

26. Temporary method of determining the preventable environmental damage (Russian State Environmental Committee 09.03.1999), ConsultantPlus (2019)

27.E. V. Ryumina, Environmental Security Modernization, Economic Science of Modern Russia 2(57): 90-100 (2012)

28. J. Weyant, Some Contributions of Integrated Assessment Models of Global Climate Change, Review of Environmental Economics and Policy 11: 115-137 (2017)

29. W. D. Nordhaus, Revisiting the social cost of carbon, PNAS (Proceedings of the National Academy of Sciences of the United States of America) 114(7): 1518-1523 (2017)

30.S. Schneider, Integrated assessment modeling of global climate change: Transparent rational tool for policy making or opaque screen hiding value-laden assumptions?, Environmental Modeling \& Assessment 2(4): 229-249 (1997)

31.R. S. Pindyck, The Use and Misuse of Models for Climate Policy, Review of Environmental Economics and Policy 11(1): 100-114 (2017) 